Doi: HTTPS://DOI.ORG/10.23910/2/2020.0388

\title{
Economic Analysis of Groundnut Production in Andhra Pradesh
}

\section{G. P. Sunandini ${ }^{1^{*}}$ and Irugu Shakuntala Devi ${ }^{2}$}

${ }^{1}$ Dept. of Agricultural Economics, College of Agriculture, Professor Jayashankar Telangana State Agricultural University, Hyderabad, Telangana (500 030), India

${ }^{2}$ Regional Agricultural Research Station, Palem, Professor Jayashankar Telangana State Agricultural University, Nagarkurnool, Telangana (509 215), India

\section{Corresponding Author}

G. P. Sunandini

e-mail: sunandini.gp@gmail.com

\section{Article History}

Article ID: IJEP0388

Received in $29^{\text {th }}$ September, 2020

Received in revised form $05^{\text {th }}$ November, 2020

Accepted in final form $15^{\text {th }}$ November, 2020

\section{Abstract}

For the study on cost of cultivation of groundnut crop in Andhra Pradesh, the data was obtained from Directorate of Economics and Statistics, Ministry of Agriculture, Government of India. The cost of cultivation was found to be Rs. 55142.26. Among the operational costs, labour cost accounted to a major share of $60 \%$, indicating the labour intensive nature of groundnut cultivation. The cost of cultivation and the gross returns analysed during the two periods noted that cost of cultivation (C2) increased by $40 \%$ where as $A 2+F L$ increased by $52 \%$ against the increase of $25 \%$ in the gross returns. The cost of production was higher in Andhra Pradesh than other major groundnut producing states Gujarat and Tamil Nadu. The cost of cultivation needs to be reduced by opting good management practices and more mechanization so as to make groundnut cultivation profitable in Andhra Pradesh.

Keywords: Cost of cultivation, economics, groundnut, returns

\section{Introduction}

One of the important legume crops of tropical and semiarid regions is groundnut, major source of edible oil and protein. Groundnut kernels contain $47-53 \%$ oil and $25-36 \%$ protein (Prasad et al., 2010; Banla et al., 2018; Taru et al., 2008). The major producers of groundnut are India, China and USA, which together account for over two-thirds of global output. Other important producers are Nigeria, Senegal, Sudan and Argentina (Freman et al., 1999). India ranks first in the production of groundnut production among the major edible oilseed crops (Rai et al., 2016). Major states producing groundnut are Gujarat, Rajasthan, Andhra Pradesh, Tamil Nadu, Karnataka, Madhya Pradesh, Telangana, Maharashtra and West Bengal. Andhra Pradesh stands third in groundnut production after Gujarat and Rajasthan (Table 1). The present study was carried out with an objective of analysing the profitability of groundnut in Andhra Pradesh over the past decade.

\section{Materials and Methods}

The cost concepts approach of farm costing is widely used in India (Raju and Rao, 1990). These cost concepts include Cost $A 1, A 2, B 1, B 2, C 1, C 2$, and C3.

COST $A_{1}$ includes value of hired human labour, value of hired

\begin{tabular}{llcc}
\hline \multicolumn{3}{l}{ Table 1: Indian Production of Groundnut } \\
\hline S r. & State & $\begin{array}{c}\text { Production } \\
\text { (000 Tonnes) }\end{array}$ & $\begin{array}{c}\text { Share } \\
\text { No. }\end{array}$ \\
\hline 1. & Gujarat & $3,940.00$ & 42.92 \\
2. & Rajasthan & $1,260.00$ & 13.73 \\
3. & Andhra Pradesh & $1,040.00$ & 11.33 \\
4. & Tamil Nadu & 970 & 10.57 \\
5. & Karnataka & 560 & 6.1 \\
6. & Madhya Pradesh & 350 & 3.81 \\
7. & Telangana & 350 & 3.81 \\
8. & Maharashtra & 330 & 3.59 \\
9. & Others & 210 & 2.29 \\
10. West Bengal & 170 & 1.85 \\
& Total & $9,180.00$ & \\
\hline
\end{tabular}

Source: Ministry of Agriculture

bullock labour, value of owned bullock labour, value of owned machinery labour, hired machinery charges, value of seed (both farm produced and purchased), value of insecticides and pesticides, value of manure (owned and purchased), value of fertilizer, depreciation on implements and farm buildings, 
irrigation charges, land revenue, cess and other taxes, interest on working capital, miscellaneous expenses.

$\operatorname{COST} A_{2}=\operatorname{COST} A_{1}$ trent paid for leased in land

$\operatorname{COST} B_{1}=\operatorname{COST} A_{1}+$ interest on value of owned fixed capital assets (excluding land)

$\operatorname{COST} B_{2}=\operatorname{COST} B_{1}+$ rental value of owned land (net of land revenue)+rent paid for leased land

COST $C_{1}=\operatorname{COST} B_{1}+$ imputed value of family labour

$\operatorname{cOST} C_{2}=\operatorname{COST} B_{2}$ +imputed value of family labour

$\operatorname{cosT} C_{3}=\operatorname{COST} C_{2}+$ value of management input at $10 \%$ of total cost $\left(\mathrm{C}_{2}\right)$

The secondary data pertaining to the cost of cultivation of the groundnut crop for combined Andhra Pradesh for different years were collected from Directorate of Economics and Statistics, Ministry of Agriculture, Government of India. The statistical tools viz., simple averages, trends, percentages, growth rates and regression analysis were applied to analyze the data.

\section{Results and Discussion}

\subsection{Costs and returns of groundnut cultivation}

The component wise cost of cultivation of groundnut in Andhra Pradesh state in the past decade (2007-08 to 2016-17) was analysed to know the contribution of different components to the cost of cultivation (Table 2). It was observed that the operational costs accounted for $66 \%$ of the total cost, while fixed costs accounted for $34 \%$. It is interesting to note that out of the operational costs, labour cost accounted for $60 \%$ indicating the labour intensive nature of groundnut cultivation. Under labour use cost, human labour occupied the major share followed by machine labour cost. Out of the material costs, seed occupied the major share of $22 \%$ indicating that seed cost is the major component in groundnut cultivation (Ani et al., 2013).

3.2. Difference in the cost of cultivation (C2) (₹ $h a^{-1}$ ) of Groundnut in Andhra Pradesh: Period I (2007-08 to 2011-12) and Period II (2012-13 to 2016-17)

The difference in the cost of cultivation (C2) (₹ ha-1) of groundnut in Andhra Pradesh between two periods Period I (2007-08 to 2011-12) and Period II ( 2012-13 to 2016-17) was analysed and presented in Table 3. The analysis revealed that per hectare cost of cultivation (C2) increased by $40 \%$ in the period II. It was noted that operational costs increased by $52 \%$ compared to fixed costs which increased by $18 \%$. Highest increase is observed in fertilizer cost followed by seed and machine labour cost indicating that the farmers' expenditure on these components increased due to excessive use of fertilizers. Considerable increase in seed cost was also observed indicating the importance of this component in the groundnut cultivation. The increase in the machine labour cost
Table 2: Average cost of cultivation (C2) of groundnut in Andhra Pradesh (2007-08 to 2016-17)

\begin{tabular}{lcc}
\hline Particulars & Rs ha ${ }^{-1}$ & $\begin{array}{c}\text { \% of total } \\
\text { cost }\end{array}$ \\
\hline Operational cost & 36261.54 & 65.76 \\
Human labour & 17336.27 & 31.44 \\
Bullock labour & 1608.52 & 2.92 \\
Machine labour & 2730.14 & 4.95 \\
Seed & 7921.71 & 14.37 \\
Farm yard manure and fertilizers & 4143.45 & 7.51 \\
Insecticides & 702.98 & 1.27 \\
Irrigation charges & 870.12 & 1.58 \\
Others & 26.81 & 0.05 \\
Interest on working capital & 921.55 & 1.67 \\
Fixed cost & 18880.72 & 34.24 \\
Rental value of owned land & 16328.66 & 29.61 \\
Rent paid for leased in land & 388.65 & 0.70 \\
Land revenue, cess and taxes & 0.80 & 0.00 \\
Depreciation on implements and & 289.52 & 0.53 \\
buildings & & \\
Interest on fixed capital & 1873.09 & 3.40 \\
Total cost (C2) & 55142.26 & 100.00 \\
\hline
\end{tabular}

may be due to non-availability of human labour and increased emphasis on mechanization (Raut et al., 2015).

The difference in the cost of cultivation as per the cost concepts ( $₹ \mathrm{ha}^{-1}$ ) of groundnut in Andhra Pradesh between two periods (2007-08 to 2011-12 and 2012-13 to 2016-17 is presented in Table 4. Cost A1, Cost A2, Cost B1, Cost B2, Cost $\mathrm{C} 1$ and Cost $\mathrm{C} 2$ were calculated and presented. For this, revised methodology of CCS (Comprehensive Cost of Cultivation Scheme) was followed.

Cost A1 showed increase of 51.79\% in 2012-17 over 2007-12, Cost A2 was found to be increased by 52.64 , Cost B1, Cost B2 showed increase of $49.33,38.90 \%$ in $2012-17$ over $2007-12$ (Table 4). Cost C1 showed an increase of 39.69\% over 2007-12. Cost C2 was 44366.436 for a period of 2007-08 to 2011-12 and 61973.79 for the period of 2012-13 to 2016-17. There was increase of $39.69 \%$ in 2012-17 over 2007-12. The increase in costs is clearly visible in both paid out costs and fixed costs.

The cost of cultivation ( $₹ \mathrm{ha}^{-1}$ ) and the gross returns analysed during the two periods noted that cost of cultivation (C2) increased by $40 \%$ whereas $A 2+F L$ increased by $52 \%$ against the increase of $25 \%$ in the gross returns. The net return over $\mathrm{C} 2$ was positive in the first period but negative in the second period as shown in Table 5 . However, net returns over $\mathrm{A} 2+\mathrm{FL}$ was positive in both the periods. The cost of production 


\begin{tabular}{lccccc}
\hline \multicolumn{5}{l}{ Table 3: Difference in the cost of cultivation (C2) (₹ ha $^{-1}$ ) of groundnut in Andhra Pradesh between two periods } \\
\hline Particulars & $\begin{array}{c}\text { 2007-08 to } \\
\text { \% of total } \\
\text { cost }\end{array}$ & $\begin{array}{c}2012-13 \text { to } \\
2011-12\end{array}$ & $\begin{array}{c}\text { \% of total } \\
\text { cost }\end{array}$ & $\begin{array}{c}\text { \% increase in 2012- } \\
17 \text { over 2007-12 }\end{array}$ \\
\hline Operational cost & 28367.51 & 63.94 & 43034.17 & 69.44 & 51.70 \\
Human labour & 14703.24 & 33.14 & 18870.01 & 30.45 & 28.34 \\
Bullock labour & 1352.57 & 3.05 & 1891.92 & 3.05 & 39.88 \\
Machine labour & 2121.28 & 4.78 & 3383.88 & 5.46 & 59.52 \\
Seed & 5372.94 & 12.11 & 10322.47 & 16.66 & 92.12 \\
Farm yard manure and fertilizers & 2685.51 & 6.05 & 5719.30 & 9.23 & 112.97 \\
Insecticides & 680.78 & 1.53 & 756.45 & 1.22 & 11.12 \\
Irrigation charges & 714.47 & 1.61 & 951.24 & 1.53 & 33.14 \\
Others & 19.12 & 0.04 & 42.65 & 0.07 & 123.06 \\
Interest on working capital & 717.61 & 1.62 & 1096.27 & 1.77 & 52.77 \\
Fixed cost & 15998.92 & 36.06 & 18939.62 & 30.56 & 18.38 \\
Rental value of owned land & 13718.75 & 30.92 & 16133.38 & 26.03 & 17.60 \\
Rent paid for leased in land & 275.70 & 0.62 & 627.00 & 1.01 & 127.42 \\
Land revenue, cess and taxes & 0.81 & 0.00 & 0.75 & 0.00 & -7.41 \\
Depreciation on implements and & 312.74 & 0.70 & 242.63 & 0.39 & -22.42 \\
buildings & & & & & 14.49 \\
Interest on fixed capital & 1690.93 & 3.81 & 1935.87 & 3.12 & 39.69 \\
Total cost (C2) & 44366.44 & 100.00 & 61973.79 & 100.00 & \\
\hline
\end{tabular}

Table 4: Difference in the cost of cultivation as per the cost concepts ( $₹$ ha $^{-1}$ ) of Groundnut in Andhra Pradesh between two periods

\begin{tabular}{lccc}
\hline Particulars & $2007-08$ to 2011-12 & $2012-13$ to 2016-17 & \% increase in 2012-17 over 2007-12 \\
\hline Cost A1 & 23994.532 & 36420.25 & 51.79 \\
Cost A2 & 24270.228 & 37047.24 & 52.64 \\
Cost B1 & 25685.46 & 38356.12 & 49.33 \\
Cost B2 & 39679.888 & 55116.49 & 38.90 \\
Cost C1 & 30371.988 & 45213.42 & 48.87 \\
Cost C2 & 44366.436 & 61973.79 & 39.69 \\
\hline
\end{tabular}

\begin{tabular}{lcccccc}
\hline \multicolumn{2}{l}{ Table 5: Variation in costs and returns of groundnut cultivation in two periods (₹ ha-1) } \\
\hline Year & $\begin{array}{c}\text { Cost of culti- } \\
\text { vation (C2) }\end{array}$ & $\begin{array}{c}\text { Cost of culti- } \\
\text { vation (A2+FL) }\end{array}$ & $\begin{array}{c}\text { Gross re- } \\
\text { turns }\end{array}$ & $\begin{array}{c}\text { Net returns } \\
\text { over Cost C2 }\end{array}$ & $\begin{array}{c}\text { Net returns } \\
\text { over cost A2+FL }\end{array}$ & $\begin{array}{c}\text { Cost of Production } \\
\text { over C2 (₹ q }\end{array}$ \\
\hline 2007-08 to 2011-12 & 44366.44 & 28956.76 & 46331.77 & 1965.33 & 17375.01 & 2402 \\
2012-13 to 2016-17 & 61973.79 & 43904.54 & 57829.56 & -4144.23 & 13925.02 & 4424 \\
\hline
\end{tabular}

registered an increase of $84 \%$ in this period.

The Comparative cost of production with other states in the country is presented in Table 6 which shows that Maharashtra has highest cost of production over the years followed by Andhra Pradesh, Tamil Nadu, Gujarat and Rajasthan. The cost of production was higher in Andhra Pradesh than other major groundnut producing states Gujarat and Tamil Nadu. This may be due to low productivity of groundnut in AP.
Table 6: Comparison of cost of production (₹ $\left.q^{-1}\right)$ with other states in the country

\begin{tabular}{lccccc}
\hline Year & $\begin{array}{c}\text { Andhra } \\
\text { Pradesh }\end{array}$ & Gujarat & $\begin{array}{c}\text { Rajast- } \\
\text { han }\end{array}$ & $\begin{array}{c}\text { Tam- } \\
\text { ilnadu }\end{array}$ & $\begin{array}{c}\text { Maha- } \\
\text { rastra }\end{array}$ \\
\hline $2014-15$ & 4607.64 & 3409.54 & 3777.03 & 3571.59 & 5783.84 \\
$2015-16$ & 4058.00 & 3288.94 & 2316.16 & 4003.67 & 7243.58 \\
$2016-17$ & 5019.01 & 3212.08 & 2495.15 & 4122.00 & 9355.86 \\
\hline
\end{tabular}




\section{Conclusion}

The total cost of cultivation increased significantly in the past decade. Among the operational costs, labour cost contributed $66 \%$ indicating the labour intensive nature of the crop. Among the material costs, seed cost contributed $22 \%$ of the operational costs. Though, the gross returns recorded increase in the past decade, the net returns over $\mathrm{C} 2$ cost of cultivation is negative in the second period. Based on the results it can be concluded that the cost of cultivation is to be reduced by good management practices and more mechanization so as to make groundnut cultivation profitable in Andhra Pradesh.

\section{References}

Ani, D.P., Umeh, J.C., Weye, E.A., 2013. Profitability and economic efficiency of groundnut production in Benue state, Nigeria. African Journal of Food, Agriculture, Nutrition and Development 13, 8091-8105.

Banla, E.M., Dzidzienyo, D.K., Beatrice, I.E., 2018. Groundnut production constraints and farmers' trait preferences: a pre-breeding study in Togo. Journal of Ethnobiology and Ethnomedicine 14, 75. https://doi.org/10.1186/ s13002-018-0275-y.

Freman, H.A, Nigam, S.N., Kelley, T.G., Ntare, B.R., Subrahmanyam, P., Boughton, D., 1999. The world groundnut economy facts, trends and outlook. Monograph. International Crops Research Institute for the Semi-Arid Tropics, Patancheru, Andhra Pradesh, India. ISSN 1817-3047.

Prasad, P.V.V., Kakani, V.G., Upadhyaya, H.D., 2010. Growth and production of groundnut. In: Soils, Plant Growth and Crop Production. Encyclopedia of Life Support Systems (EOLSS), Developed under the Auspices of the UNESCO, Oxford UK, 1-26.

Rai, S.K., Charak, D., Bharat, R., 2016. Scenario of oilseed crops across the globe. Plant Archives 16, 125-132.

Raju, V.T., Rao, D.V.S., 1990. Economics of farm production and management. Oxford and IBH Publishing. Co. Pvt Ltd, New Delhi.

Raut, V., Thakur, K.P., Chaudhari, D.D., Workneh, Yigzaw S., 2015. Cost of cultivation of kharif groundnut in Sabarkantha district of Gujarat state. International Research Journal of Agricultural Economics and Statistics 6, 186-188.

Taru, V.B., Kyagya, I.Z., Mshelia, S.I., Adebayo, E.F., 2008. Economic efficiency of resource use in groundnut production in Adamawa state of Nigeria. World Journal of Agricultural Sciences 4, 896-900. 